\title{
Proses Dinamika Pembentukan Identitas Sosial pada kelompok:Studi Kasus Geng Motor Ghost Night di Pekanbaru
}

\author{
Leni Armayati.*1, Zulriska Iskandar², \\ Ahmad Gimmy P. Siswandi, ${ }^{3}$, Zainal Abidin ${ }^{4}$ \\ 1,2,3,4, Fakultas Psikologi Universitas Padjajaran, Bandung, Indonesia \\ ${ }^{*}$ Fakultas Psikologi Universitas Islam Riau, Pekanbaru, Riau, Indonesia \\ email: *1leni.armayati@psy.uir.ac.id
}

\begin{abstract}
Abstrak
Artikel INFO

Diterima:01 April 2019

Direvisi :05 April 2019

Disetujui: 05 Juli 2019

DOI:

http://dx.doi.org/10.24014/

jp.v14i2.6847

Penelitian ini bertujuan untuk mengetahui dinamika pembentukan identitas sosial pada kelompok geng motor Ghost Nightdi kota Pekanbaru. Metode yang digunakan dalam penelitian ini adalah kualitatif studi kasus. Penelitian ini menggunakan tiga subjek yang tergabung dalam geng motor Ghost Night selama lima tahun. Setelah melakukan observasi, peneliti mengambil data lewat wawancara semi-terstruktur.Hasil penelitian menunjukkan bahwa dinamika pembentukan identitas sosial setiap anggota geng motor Ghost Night dibentuk oleh otoritas geng atau ketua untuk kemudian terjadi identifikasi diikuti dengan menggunakan simbol tertentu sebagai bentuk komitmenidentitas social dalam kelompok geng motor Ghost Night terbentuk. Identitas sosial yang terbentuk setiap anggota kelompok geng motor Ghost Night dipertahankan kelompok dengan penciptaan rasa takut dengan otoritas dalam kelompok. Oleh sebab itu, setiap anggota geng motor Ghost Night tidak mempunyai keberanian untuk menolak perintah dan melanggar apa yang dikatakan oleh pemimpin kelompok. Ancaman dan hukuman secara fisik yang dilakukan oleh pemimpin kelompok adalah cara pemimpin kelompok membentuk kelompok geng motor Ghost Night.
\end{abstract}

Kata kunci: identitas sosial, geng motor, remaja.

\begin{abstract}
This study aims to describe the group dynamics and the formation of social identity in the Ghost Night motorcycle gang. The method used in this study is a qualitative case study. This study used three subjects that were incorporated in the Ghost Night motorcycle gang for five years. After making observations, researchers take data through semi-structured interviews. The results showed that the social identity of each Ghost Night motorcycle gang member was formed by the authority to then form the internal dynamics of the Ghost Night motorcycle gang group formed. The social identity formed by each member of the Ghost Night motorcycle gang group is maintained by the group by creating fear with authority in the group. Therefore, every member of the Ghost Night motorcycle gang does not have the courage to refuse orders and violate what the group leader says. Physical threats and punishments carried out by group leaders are the way group leaders form Ghost Night motorcycle gang groups.
\end{abstract}

Keywords: social identity, motorcycle gang, teenager

\section{Pendahuluan}

Anggota geng motor remaja umumnya masih sekolah, setingkat sekolah tingkat pertama dan setingkat sekolah menengah.
Aktivitas yang sering mereka lakukan adalah tawuran, kebut-kebutan, perkelahian antar geng yang dijadikan lawan tanding. Meskipun demikian, ada perbedaan karakteristik geng 
motor yang melakukan aksi kekerasan pada masa kini dibandingkan masa-masa awal munculnya geng motor. Berdasarkan identitas sekolah, beberapa geng motor remaja yang melakukan aksi kekerasan sedangkan pada masa kinitidak berdasarkan identitas sekolah.

Perubahan ekspresi kekerasan yang dulunya menjadi aktivitas geng motor sekolah menjadi sangat berbeda ketika melihat fakta yang terjadi pada dua tahun belakangan ini. Pada masa kini, aksi dan kekerasan menjadi salah satu aktivitas geng motor remaja yang berdiri bukan atas identitas sekolah yang sama. Media cetak Motor plus-online. com mengabarkan bahwa aksi kriminalitas memang rawan terjadi, ada satu orang korban yang mengalami luka bacok yang cukup serius ketika berpapasan dengan sekelompok pemotor atau geng motor yang mebawa senjata tajam. Kasus-kasus ini juga semakinmemancing perhatian dengan adanya peningkatan kasus kriminalitas di Pekanbaru. Pada tahun 2012 tercatat ada 6.780 kasus kriminal yang dicatat oleh Polda Riau dan pada tahun 2013 jumlah kasus kriminal menurun menjadi 6.513 kasus.

Selanjutnya, tercatat pada tahun 2014 jumlah kasus kriminal meningkat 193,98\% (Seksi Statistik Ketahanan Nasional \& Bidang Statistik, 2015). Meskipun tidak bisa diketahui secara pasti berapa jumlah geng motor yang melakukan kriminalitas jalanan dengan ini, namun kemunculan geng motor baru ini ikut berkontribusi dalam meningkatnya jumlah kriminalitas yang tercatat.

Menurut Kartono (2014) geng motor remaja banyak ditemukan dan berkembang di kota-kota besar. Pada awalnya, mereka merupakan sekumpulan remaja yang membentuk kelompok bermain dan mencari pengalaman baru secara bersama-sama.Dari pencarian pengalaman ini, sangat mungkin untuk terjadi perubahan yang tidak lagi bisa dikontrol dan menghadirkan kekerasan, pencurian, perusakan fasilitas umum ataupun fasilitas pribadi.Perilaku ini kemudian menciptakan teror dalam masyarakat (Ahnaf \& Salim, 2017).
Berdasarkan hasil wawancara dengan mantan pelaku geng motort; $B M, R L$, dan AR menuturkan awal mula mengikuti geng motor sekolah sejak kelas X SMA. Sudah menjadi tradisi di SMA-nya, siswa laki-laki hendaknya mengikuti geng motor sebab "anak laki-laki sudah sewajarnya kalau senang berkelahi". $\mathrm{RL}$ menceritakan bahwa awal mula mengikuti geng motor karena ajakan dari teman dan para senior-senior di sekolah, kemudian dari ajakan tersebut RL mulai aktif dalam kegiatan-kegiatan geng motor sekolah seperti tawurandengan geng motor sekolah lain yang dianggap musuh.

Aktivitas yang dilakukan tidak hanya menggunakan senjata tapi juga menggunakan senjata tumpul. BM, RL, dan $\mathrm{RL}$ juga menjelaskan bahwa tawuran, hanya membuat lawan cidera dan meminta ampun, yang nantinya akan membuat bangga mereka dan geng motornya. Artinya, penyerangan mematikan tidak menjadi perhatian utama kegiatan anggota geng motor tapi cenderung menakuti lawan mereka, baik lawan yang tergabung dalam anggota geng motor maupun tidak.

Aksi tersebut dilakukan dengan cara berkeliling dalam gerombolan sambil mengendarai motor dan membawa senjata tajam. Lawan yang akan menjadi mangsa mereka biasanya adalah kelompok lain atau orang yang dianggap sebagai musuh. Namun terkadang juga siapa-siapa yang ditemui di jalan dan dianggap meledek atau bersikap tak menyenangkan akanmereka serang.

Persoalan label identitas mengalami perubahan dalam hal ini. Kepentingan geng motor pada dua tahun belakangan ini membentuk identitas sosial baru yang tidak berdasarkan sekolah. Menurut Hogg \& Abrams (1988) Identitas sosial adalah pengetahuan tentang masing-masing orang selama individu tersebut berada di dalam sebuah kelompok.

Identitas sosial juga menunjukkan bahwa semua perilaku di dalam kelompok terbentuk, seperti bagaimana setiap masingmasing individu mempunyai solidaritas terhadap kelompoknya ataupun kepada teman satu kelompok yang mempunyai tujuan untuk mendapatkan pengakuan atau penghargaan 
secara positif (Hogg \& Abrams 1988).

Menurut Tajfel dan Turner dalam ( Hogg \& Abrams, 1988) perbandingan antar kelompok berfokus pada pembentukan dan keunikan masing-masing kelompok. Pembentukan terbangun karena adanya solidaritas antar setiap anggota kelompok dan sosok yang mendominasi kelompok (Turner, dkk.,dalam Sarwono, 2009). Rasa solidaritas yang tumbuh di dalam kelompok dirasa sangat penting, maka identitas sosial berpotensi rusak jika rasa solidaritas di dalam kelompok sudah tidak terjalin (Walgito, 2010).

Lewat paparan di atas, penelitian ini tertarik untuk melihat bagaimana proses dinamika pembentukan identitas sosial lewat studi kasus terhadap geng motor Ghost Nightyang biasa melakukan aktivitas kriminalitasdi Pekanbaru. Perubahan bentuk pada tiga tahun belakangan yaitu tahun 2007 sampai dengan 2011 ini jauh sangat berbeda dengan aktivitas yang dilakukan. Pada tahun 2007 sampai pada tahun 2011 anggota geng motor cenderung berkumpul dan melakukan aktivitasnya setelah pulang dari sekolah dimana mereka selalu berkumpul disepanjangjalan Diponegoro dan Ronggowarsito. Berbeda dengan tahun 2013 sampai dengan sekarang dimana aktivitas anggota geng motor cenderung berkumpul pada tengah malam untuk melakukan atraksiatraksi. Dalam segi jumlah anggota geng motor wanita lebih meningkat disbanding tahun 2007 sampai dengan 2011. Nantinya akan ditunjukkan bahwa pembentukan identitas sosial ini bukan sesuatu yang secara cair terbentuk dari kelompok bermain dan mengalami perubahan pola perilaku. Justru sebaliknya, geng motor merupakan salah satu contoh bahwa identitas sosial rentan untuk direkayasa dan dimanfaatkan pihak-pihak tertentu. Tujuan dari penelitian ini adalah :

1. Mendeskripsikan dinamika kelompok dalam geng motor Ghost Night.

2. Menjelaskan pembentukan identitas dalam geng motor Ghost Night.

\section{Identitas Sosial}

Menurut Tajfel (1986), identitas sosial adalah bagian dari konsep diri seseorang yang berasal dari pengetahuanmereka tentang keanggotaan dalam suatu kelompok sosial bersamaan dengansignifikansi nilai dan emosional dari keanggotaan tersebut. Identitas sosial berkaitan dengan keterlibatan, rasa peduli dan juga rasa bangga dari keanggotaandalam suatu kelompok tertentu. Hogg danAbrams (1988) menjelaskan identitas sosial sebagai rasaketerkaitan, peduli, bangga dapat berasal dari pengetahuan seseorang dalamberbagai kategori keanggotaan sosial dengan anggota yang lain, bahkan tanpaperlu memiliki hubungan personal yang dekat, mengetahui atau memiliki berbagaiminat

Jones dan Volpe (2014) mengatakan bahwa aspek-aspek identitas sosial adalah :

a. Kategorisasi, pengelompokan individu kedalam kelompok-kelompok tertentu dan memberikan label berdasarkan kelompoknya.

b. Identifikasi, individu mengasosiasikan dirinya kedalam kelompok tertentu ingroup.

c. Membandingkan,individu membandingkan kelompoknya dengan kelompok lain out-group

\section{Geng Motor}

Menurut Hobsbawm (2000), istilah geng motorseringkalidigunakanuntukmenunjukkan anggota atau organisasi kelompok yang erat kaitannya dengan kriminalitas. Geng motor mampu menyelidiki tentang hubungan sebab akibat didalam kelompok sehingga memiliki persepsi sesuai dengan keanggotaan dalam kelompok sosial. Kelompok geng motor rataratamempunyaianggota kelompokyang cukup banyak mulai dari 3-50 anggota (Kartono, 2014). Masyarakat luas memandang bahwa anggota geng motor merupakan gerombolan preman atau bandit yang meresahkan lingkungan di mana mereka berada.

Menurut Ryter (2011) pada tahun 1998 pertumbuhan geng motor di Indonesia sangat cepat dan awal terbentuknya mulai dari perkumpulan-perkumpulan yang ada di kampung, sekolah-sekolah,terminal, stasiun, dan tempat-tempat keramaian seperti gedunggedung bioskop.

Menurut Santrok (2002) karateristik 
siswa sebagai remaja mengalami masa transisi sosial yaitu perubahan dalam hubungan individu dengan manusia lain, baik dalam sosial, dalam kepribadian, dan dalam peran konteks sosial.Sehingga remaja mengalami masa krisis identitas yang menyebabkan kurangnya kontrol pada individu yang mempengaruhi konteks hubungan sosial pada remaja.Hal itu membuat remaja-remaja yang masih berada di bangku Sekolah Menengah Atas mudah ikut masuk ke dalam geng motor, di dalam geng motor remaja juga terdapat sosok pemimpin yang selalu mengkoordinasi setiap aktivitas gengnya seperti tawuran antara geng motor sekolah yang lain dan sosok pemimpin mempunyai strategi untuk membalas atau yang disebut (Kadir, 2012).

\section{Metode}

Peneliti menggunakan metode kualitatif yaitu mengumpulkan data dengan cara wawancara dan observasi karena dirasa tepat untuk memenuhi tujuan penelitian, yaitu untuk menggambarkan dinamika pembentukan identitas sosial kelompok geng motor Ghost Night. Penelitian kualitatif berusaha untuk mengeksplorasi, mendeskripsikan maupun menginterpretasikan maksud dari suatu fenomena maupun pengalaman personal dan sosial yang dialami oleh subjek penelitian (Smith, 2009).

Secara khusus, pendekatan kualitatif yang digunakan dalam penelitian ini merupakan pendekatan studi kasus.Menurut Creswell (2007) studi kasus merupakan suatu pendekatan yang melibatkan studi terhadap sebuah isu yang dieksplorasi melalui satu atau lebih kasus dalam sebuah sistem yang saling berkaitan.Pendekatan studi kasus dalam penelitian ini memiliki sumber data yangdikumpulkan lewat wawancara dan observasi (Strauss \& Corbin, 2008).

\section{Fokus Penelitian}

Penelitian ini berfokus pada kelompok geng motor Ghost Night dan aktivitas yang dilakukan oleh kelompok tersebut, baik dalam proses pembentukan geng motor maupun pengorganisiran identitas sosial di dalamnya.

\section{Subjek Penelitian}

Subjek dipilih berdasarkan kriteria tertentu (Criterion Sampling) yang mewakili populasi dalam kelompok (Creswell, 2007). Subjek atau informan dalam penelitian ini berjumlah dua orang dan memilikikriteria sebagai berikut:

1. Tergabung dalam kelompok geng motor selama kurang lebih lima tahun dan kini mengikuti kelompok geng motor Ghost Night

2. Pernah melakukan aktivitas kekerasan

\section{Prosedur Analisis Data}

Dalam penelitian kualitatif tidak ada rumusan baku untuk melakukan analisis data. Namun, terdapat beberapa hal yang yang harus diperhatikan dalam pengolahan dan analisis data yaitu, peneliti wajib memonitor dan melaporkan proses dan prosedur analisis data secara jujur dan selengkap mungkin senada dengan yang diungkapkan Patton (dalam Poerwandari, 2005).Berikut ini adalah langkah analisis data dalam penelitin ini: organisasi data, pengkodean (coding), interpretasi dan pembahasan.

\section{Hasil}

Hasil temuan lapangan anggota geng motor sebenarnya ingin mendapatkan penghargaan yang diberikan oleh pemimpin kelompok. Bentuk penghargaan itu berupa pengakuan ataupun pujian dari pemimpin. Selain itu, pemimpin akan memberikan minuman beralkohol dan narkobasecara cuma-cuma sebagai bentuk penghargaan atas aktivitas anggota geng.

Dari penghargaan yang diberikan oleh pemimpin kelompok tersebut muncul kesenangan yang didapatkan.Kesenangan itu timbul setelah pemimpin kelompok memberi pujian dan minuman beralkohol dan narkoba secara gratis. Kemudian, pemimpin kelompok akan memberikan bonus yang lebih untuk para anggota yang telah melaksanakan perintahnya. Bonus tersebut bisa berupa anggota kelompok akan diajak ketempat diskotik ataupun tempat karaoke. 
Otoritas dan identitas dari pemimpin kelompok dan anggota kelompok.Di mana pemimpin kelompok sangat ditakuti dan disegani oleh anggota kelompok dengan ancaman-ancaman fisik yang sering kali diberikan. Selain itu, identitas sosial anggota geng motor yang termanifestasikan dalam bentuk kegiatan atau aktivitas kekerasan berawal dari perintah yang diberikan oleh pemimpin.

Identitas terbentuk karena adanya rasa takut karena adanya ancaman-ancaman fisik oleh pemimpin kelompok.Rasa takut itu yang kemudian membuat anggota kelompok berani melakukan aktivitas tersebut. Ketika ada salah satu anggota kelompok yang memutuskan untuk keluar dari kelompok tersebut maka pemimpin akan mencari keberadaannya dan dipaksa untuk kembali ikut kedalam anggota kelompok.

Ancaman secara fisik tersebut yang membuat semua anggota kelompok merasa takut dengan sosok leader atau pemimpin yang sering mereka gunakan saat proses wawancara. Terakhir atau kelima, kerentanan identitas di sini muncul karena ajakan dari orang lain untuk masuk kedalam gengster. Ketika sudah menjadi anggota geng motor pengaruh itu muncul dari pemimpin dan sesama anggota. Pengaruh pemimpin sangat besar terhadap setiap anggota kelompok. Pengaruh tersebutdilabeli dengan ancaman yang diberikan oleh pemimpin kelompok. Ini yang nantinya akan membentuk identitas sosial pada individu.

Dari perspektif humanistik Maslow, kebutuhan akan rekognisi, belonging, esteem atau penghargaan dari orang lain harus terpenuhi terlebih dahulu sebelum memenuhi tujuan pokok atau aktualisasi diri (Feist \& Feist, 2008).

Penghargaan tersebut tidak hanya diperoleh dari pemimpin kelompok saja yang memiliki struktur lebih tinggi dibanding anggotanya, melainkan juga didapat dari teman satu kelompoknya sendiri. Seperti yang dituturkan oleh subjek SN dan ANakan merasa lebih bangga dan dihargai jika teman satu kelompok memberikan apresiasi ketika berhasil melakukan pemukulan dalam aktivitas geng.

Perasaan bangga tersebut membuat kedua subjek semakin nyaman dan semakin berani melakukan aktivitas kelompoknya. Pemberian penghargaan ini mampu mengkonstruksi terbentuknya identitas sosial sebagaimana disebut oleh Hogg \& Abrams (1988) tercipta lewat perilaku kelompok, seperti solidaritas kelompok dengan tujuan untuk penghargaan diri yang positif.

Menurut Tajfel \& Turner (dalam Hogg \& Abram, 1988) menuturkan bahwa identitas sosial di dalam anggota kelompok akan sangat berpengaruh pada keyakinan kelompok dalam hubungan relasi pemimpin kelompok dananggotanya. Dalam hal ini, melakukan aktivitasmenjadi sebuah simbol kebanggaan bagi ketiga subjek.

Perasaanbangga ini muncul ketika mereka berhasil mendapatkan pujian dari pemimpin dan teman-teman satu kelompok atas perbuatannya tersebut.Perasaan bangga itulah yang membuat ketiga subjek sangat merasa senang atas pencapaiannya.

Selanjutnya, mereka akan mendapatkan minuman beralkohol dan narkoba secara gratis ketika berhasil melaksanakan perintah dari pemimpin kelompok.

Sosok leader atau pemimpin kelompok mempunyai kontribusi yang sangat besar dalam pembentukan kelompok. Seperti yang dituturkan oleh ketiga subjek yang mengaku bahwa tidak sedikitpun berani atau membantah apa yang dikatakan oleh pemimpin. Mereka tidak pernah menolak apa yang menjadi keinginan seorang leader. Subjek AN juga menuturkan jika menurut apa perintah leader akan merasa aman dan nantinya akan mendapat kesenangan yang diberikan oleh pemimpin kelompok.

Cara pemimpin inilah yang membuat kelompok tetap ada dengan segala aktivitasnya. Sosok pemimpin menjadi otoritas dalam geng motor. Seperti yang dituturkan oleh ketiga subjek bahwa leader yang mengkoordinasi maupun memberikan perintah setiap aktivitas geng.

Otoritas di dalam kelompok tersebut yang menjalankan kelompok, sehingga aktivitas tetap berjalan. Setelah aktivitas 
tersebut berjalan pemimpin kelompok akan memberikan evaluasi kepada anggotanya sesuai apa yang dipaparkan oleh subjek AN dan YN.

Identitas sosial yang berada di dalam kelompok memiliki peranan untuk mengevaluasi kelompok dan peranidentitas sosial sendiri berguna dalam pembentukan maupuntindakanyangdilakukanolehkelompok (Newcomb, Turner \& Converse, 1978).

Anggota geng motor ini sangat meneladani dan mematuhi apa yang dikatakan oleh pemimpinya. Bahkan bisa dikatakan setiap anggota kelompok tidak berani atau menolak apa yang dikatakan pemimpin. Perintah harus dilaksanakan dan setiap anggota yang berani menolak akan diberi hukuman secara fisik oleh pemimpin kelompok.

Ketiga subjek juga menuturkan hal yang senada bahwa perintah pemimpin harus dipatuhi. Seorang pemimpin mempunyai kewajiban untuk mengendalikan dan mengawasi perilaku anggota kelompok (Walgito, 2010).Dalam hal merumuskan identitas lewat rasa takut, ketiga subjek menuturkan hal yang senada terhadap ketakutannya dengan sosok leader.Ketiga subjek mengaku bahwa sering mendapat ancaman secara fisik dari pemimpin. Ancaman tersebut membuat ketiga subjek merasa sangat takut dan tidak berani menolak apa yang diperintahkan oleh leader.

\section{Pembahasan}

Kebutuhan akan rekognisi, belonging, esteem atau penghargaan dari orang lain harus terpenuhi terlebih dahulu sebelum memenuhi tujuan pokok atau aktualisasi diri (Feist \& Feist, 2008).

Penghargaan tersebut tidak hanya diperoleh dari pemimpin kelompok saja yang memiliki struktur lebih tinggi dibanding anggotanya, melainkan juga didapat dari teman satu kelompoknya sendiri. Seperti yang dituturkan oleh subjek Dp dan Gk akan merasa lebih bangga dan dihargai jika teman satu kelompok memberikan apresiasi ketika berhasil melakukan pembacokan dalam aktivitas geng.

Perasaan bangga tersebut membuat kedua subjek semakin nyaman dan semakin berani melakukan aktivitas kelompoknya. Pemberian penghargaan ini mampu mengkonstruksi terbentuknya identitas sosial sebagaimana disebut oleh (Hogg \& Abrams, 1988) tercipta lewat perilaku kelompok, seperti solidaritas kelompok dengan tujuan untuk penghargaan diri yang positif.

Menurut Tajfel \& Turner (dalam Hogg \& Abrams, 1988) menuturkan bahwa identitas sosial di dalam anggota kelompok akan sangat berpengaruh pada keyakinan kelompok dalam hubungan relasi pemimpin kelompok dan anggotanya. Dalam hal ini, melakukan aktivitasmenjadi sebuah simbol kebanggaan bagi ketiga subjek.

Perasaanbangga ini muncul ketika mereka berhasil mendapatkan pujian dari pemimpin dan teman-teman satu kelompok atas perbuatannya tersebut.Perasaan bangga itulah yang membuat ketiga subjek sangat merasa senang atas pencapaiannya.

Selanjutnya, mereka akan mendapatkan minuman beralkohol dan narkoba secara gratisketika berhasil melaksa-nakan perintah dari pemimpin kelompok.

Sosok leader atau pemimpin kelompok mempunyai kontribusi yang sangat besar dalam pembentukan kelompok. Seperti yang dituturkan oleh ketiga subjek yang mengaku bahwa tidak sedikitpun berani atau membantah apa yang dikatakan oleh pemimpin. Mereka tidak pernah menolak apa yang menjadi keinginan seorang leader. Subjek Gk juga menuturkan jika menurut apa perintah leader akan merasa aman dan nantinya akan mendapat kesenangan yang diberikan oleh pemimpin kelompok.

Cara pemimpin inilah yang membuat kelompok tetap ada dengan segala aktivitasnya. Sosok pemimpin menjadi otoritas dalam geng motor.Seperti yang dituturkan oleh ketiga subjek bahwa leader yang mengkoordinasi maupun memberikan perintah setiap aktivitas geng.

Otoritas di dalam kelompok tersebut yang menjalankan kelompok, sehingga aktivitas tetap berjalan. Setelah aktivitas 
tersebut berjalan pemimpin kelompok akan memberikan evaluasi kepada anggotanya sesuai apa yang dipaparkan oleh subjek Gk dan Po.

Identitas sosial yang berada di dalam kelompok memiliki peranan untuk mengevaluasi kelompok dan peranidentitas sosial sendiri berguna dalam pembentukan maupun tindakan yang dilakukan oleh kelompok (Newcomb, Turner \& Converse, 1978).

Anggota geng motor ini sangat meneladani dan mematuhi apa yang dikatakan oleh pemimpinya. Bahkan bisa dikatakan setiap anggota kelompok tidak berani atau menolak apa yang dikatakan pemimpin. Perintah harus dilaksanakan dan setiap anggota yang berani menolak akan diberi hukuman secara fisik oleh pemimpin kelompok.

Ketiga subjek juga menuturkan hal yang senada bahwa perintah pemimpin harus dipatuhi. Seorang pemimpin mempunyai kewajiban untuk mengendalikan dan mengawasi perilaku anggota kelompok (Walgito, 2010).Dalam hal merumuskan identitas lewat rasa takut, ketiga subjek menuturkan hal yang senada terhadap ketakutannya dengan sosok leader.Ketiga subjek mengaku bahwa sering mendapat ancaman secara fisik dari pemimpin. Ancaman tersebut membuat ketiga subjek merasa sangat takut dan tidak berani menolak apa yang diperintahkan oleh leader.

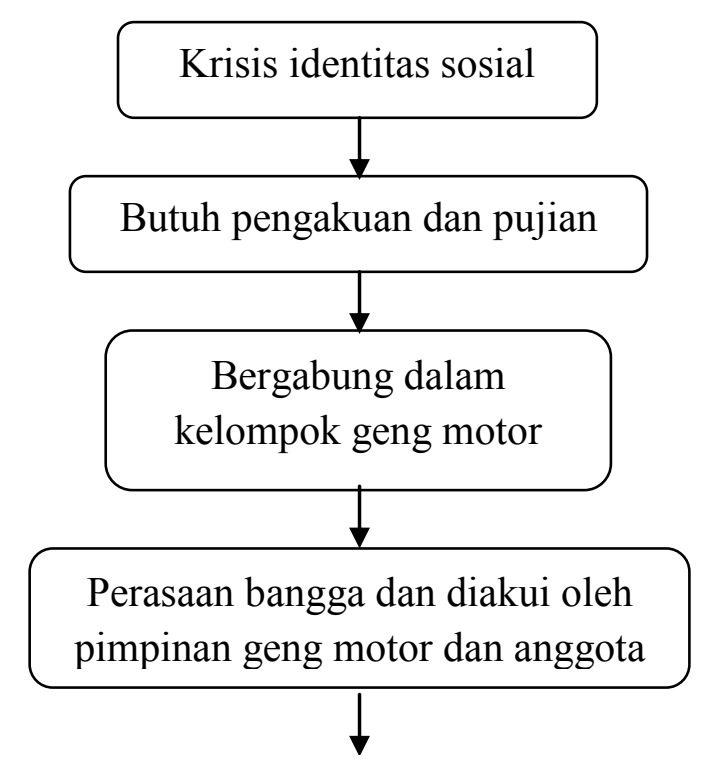

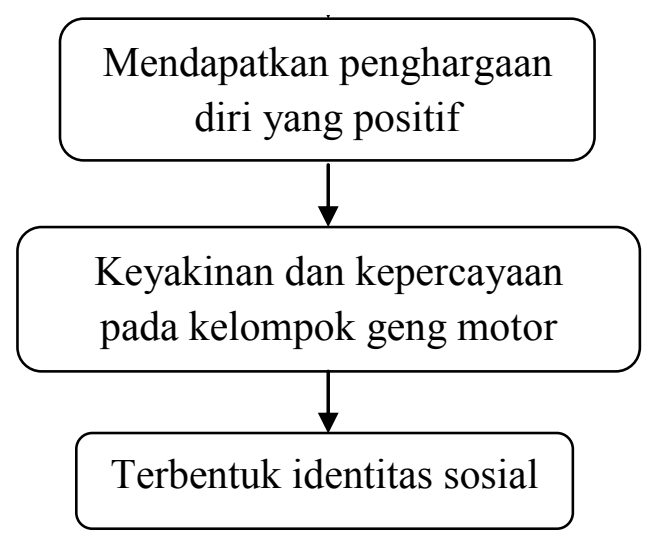

\section{Bagan 1 Dinamika Identitas Sosial}

\section{Kesimpulan}

Dari hasil penelitian dan pembahasan di atas,makadapatdisimpulkan bahwa aktivitas geng motor di Pekanbaru diorganisir oleh otoritas yang terepresentasikan lewat pemimpin kelompok. Identitas sosial anggota geng motor tersebut terbentuk karena adanya pengaruh dari pemimpin kelompok yang sering kali memberikan ancaman ataupun tekanan secara fisik kepada seluruh anggotanya. Kenyamanan anggota kelompok tersebut timbul karena adanya penghargaan yang diberikan oleh pemimpin kelompok. Pemimpin mempunyai cara sendiri untuk mempertahankan kelompok yaitu dengan ancaman fisik atau tekanan secara fisik yang nantinya membuat anggotanya menuruti dan melaksanakan perintah dari pemimpin geng motor.

\section{Daftar Pustaka}

Ahnaf, M. I., \& Salim, H. (2017).Krisis keistimewaan: Kekerasan terhadap minoritas di Yogyakarta. Yogyakarta : Penerbit CRCS (Center for Religious and Cross Cultural Studies).

Creswell, J.W. (2007). Qualitative inquiry and research design: choosing among five approaches (2nd Edition). Thousand Oaks: Sage.

Feist, J., \& Feist, G. J. (2008). Theoriest of Personality.Yogyakarta : Pustaka Pelajar.

Harimurti, A. (2017). Merayakan pembantaian preman: Fantasi dalam penyerangan 
lapas Cebongan. Tesis tidak Salemba Humanika.

dipublikasikan.Universitas Sanata Seksi Statistik Ketahanan Nasional \& Bidang Dharma.

Hobsbawn, E. J. (2000). Bandit sosial. Jakarta: Penerbit Teplok Press.

Hogg, M. A., \& Abrams, D. (1988).Social Identification.A social psychology of intergroup relations and group processes. New York: Routledge.

https://www. motorplusonline.com/ read/251722852/brutal-seorangpemudatewas-mengenaskandibacok-geng-motor-lenteng-agung mencekam?page $=$ all

Jones, C.,\&Volpe, E. H. (2014). Organizational identification: Extending our understanding of social identities through social networks.Journal of Organizational Behavior J. Organiz. Behav.

Kadir, H. A. (2012). School Gengs of Yogyakarta : Mass Fighting Strategies and Masculine Charisma in the City of Student. The Asia Pacific Journal ofAnthropology. Vol. 13, No. 4, pp. 352365.

Kartono, K. (2014). Patologi sosial 2: Kenakalan remaja. Jakarta: Raja Grafindo Persada.

Newcomb, Turner \& Converse.(1978). Psikologi Sosial.Bandung: CV. Diponegoro.

Parker, Ian. (2008). Psikologi Kualitatif. Yogyakarta : Penerbit Audi Yogyakarta

Poerwandari, E.K. (2005). Pendekatan Kualitatif Untuk Penelitian Perilaku Manusia. Jakarta: Lembaga Pengembangan Sarana Pengukuran dan Pendidikan Psikologi (LPSP3).

Ryter, L. (2011, 25 Juni). Geng dan Negara Orde Baru (1): Preman dari markas tentara. Etnohistori, edisi "Jago, Preman dan Negara”.Diunduh dari http:// etnohistori.org/geng-dan-negara-ordebaru-1-preman-dari-markastentara. html pada tanggal 18 April 2017.

Santrock, J. W. (2002). Perkembangan Masa Hidup. Jakarta. Erlangga.

Sarwono, S.W. \& Meinarno, E.A (2009). Psikologi Sosial.Jakarta : Penerbit 